Article

\title{
Synthesis and Odor Evaluation of Five New Sulfur-Containing Ester Flavor Compounds from 4-Ethyloctanoic Acid
}

\author{
Yuping Liu ${ }^{1,2}$, Haitao Chen ${ }^{2}$, Decai Yin ${ }^{2}$ and Baoguo Sun ${ }^{1,2, *}$ \\ 1 College of Chemistry and Chemical Engineering, Shaanxi University of Science and Technology, \\ Xi' an 710021, China \\ 2 School of Chemical and Environmental Engineering, Beijing Technology and Business University, \\ Beijing 100048, China
}

* Author to whom correspondence should be addressed; E-Mail: sunbg @btbu.edu.cn.

Received: 5 June 2010; in revised form: 16 July 2010 / Accepted: 27 July 2010 /

Published: 29 July 2010

\begin{abstract}
Five sulfur-containing flavor compounds were synthesized for the first time by the reaction of 4-ethyloctanoyl chloride with sulfur-containing alcohols or mercaptans. The synthesized compounds are 3-(methylthio)propyl 4-ethyloctanoate, 2-methyl-3-tetrahydrofuranthiol 4-ethyloctanoate, 4-methyl-5-thiazoleethanol 4-ethyloctanoate, 2-furanmethanethiol 4-ethyloctanoate and 2-methyl-3-furanthiol 4-ethyloctanoate. These five synthetic sulfur-containing ester flavor compounds all have meaty odor and might be used in foods if approved for this purpose in the future.
\end{abstract}

Keywords: sulfur-containing compounds; flavor; synthesis; odor characteristic

\section{Introduction}

Esters are important flavor compounds because of the large number of accessible ester compounds, their occurrence in a wide range of natural sources, various odor characteristics and their wide range of uses in flavourings. The odor of esters is related to the organic acid and alcohol from which they derived. Moreover, the odor intensity of esters decreases with the increase of molecular weight; however, the flavor industry needs esters with strong odors and high molecular weight to prolong the duration of the odor of flavorings. Esters containing sulfur can be synthesized to yield flavor 
substances with strong odor and high molecular weight, as flavor compounds containing sulfur exhibit very low odor threshold levels and very good odor characteristics.

The sulfur-containing esters can be divided into two classes; one in which the sulfur atom belongs to the organic acid, such as $\mathrm{CH}_{3} \mathrm{SCH}_{2} \mathrm{CH}_{2} \mathrm{COOCH}_{3}$, and the other in which the sulfur atom is from an alcohol or mercaptan (AOM), such as $\mathrm{CH}_{3} \mathrm{COOCH}_{2} \mathrm{CH}_{2} \mathrm{SCH}_{3}$ or $\mathrm{CH}_{3} \mathrm{COSCH}_{2} \mathrm{CH}_{2} \mathrm{CH}_{3}$. The first sulfur-containing ester class can be synthesized by the thia-Michael addition reaction, which is facile and efficient [1-3]. The second ester class can be synthesized by several methods. One method is the preparation of the ester from AOM and an organic acid in the presence of a catalyst, which can be basic, like triethylamine [4] or acidic [5,6] like solid superacids or $p$-toluenesulfonic acid. A second method is treatment of AOM with an anhydride yielding the corresponding ester [6-9]; mercaptans can be used directly as the starting reagent or can be obtained by reducing an alkyl disulfide with tributyl phophine [9]. A third method is the preparation of the esters by reaction of an acyl chloride with AOM [10-15]; however, the hydrogen chloride side product must sometimes be eliminated by pyridine addition. The fourth method is the synthesis of esters by reaction of a haloalkane with the salt of a thioorganic acid in THF [16]; these starting materials are not readily available, so this method is mainly used in the synthesis of esters from thioacetic acid.

4-Ethyloctanoic acid has a low odor threshold of $1.8 \mathrm{ppb}$ [17] and possesses an odor variously described as waxy, fatty, creamy, moldy and cheesy, with animal-like nuances; it is used in flavoring for goat meat with fatty, meaty nuances and savory notes [18]. 3-(Methylthio)propanol, 4-methyl-5thiazole ethanol, 2-methyl-3-furanthiol, 2-methyl-3-tetrahydrofuranthiol and 2-furanmethanethiol are all very important sulfur-containing flavor compounds in formulating meaty flavorings [19-22] and are also used to synthesize acetates. Their corresponding 4-ethyloctanoates would have desirable high molecular weights but have never been synthesized. We have now synthesized and evaluated the odors of the esters derived from 4-etyloctanoic acid with the above AOMs. The carbonyl in 4-ethyloctanoic acid is a weak electrophile, so 4-ethyloctanoyl chloride is synthesized as an intermediate to increase the electrophilic properties of the carbonyl group. 4-Ethyloctanoyl chloride (2) was synthesized by the reaction of thionyl chloride with 4-ethyloctanoic acid (1), and then 2 reacted with either 3(methylthio)propanol, 2-methyl-3-tetrahydrofuranthiol, 4-methyl-5-thiazoleethanol, 2-furanmethanethiol and 2-methyl-3-furanthiol, respectively (Scheme 1), to give their corresponding esters 3a-3e (Figure 1).

Scheme 1. Reaction route.
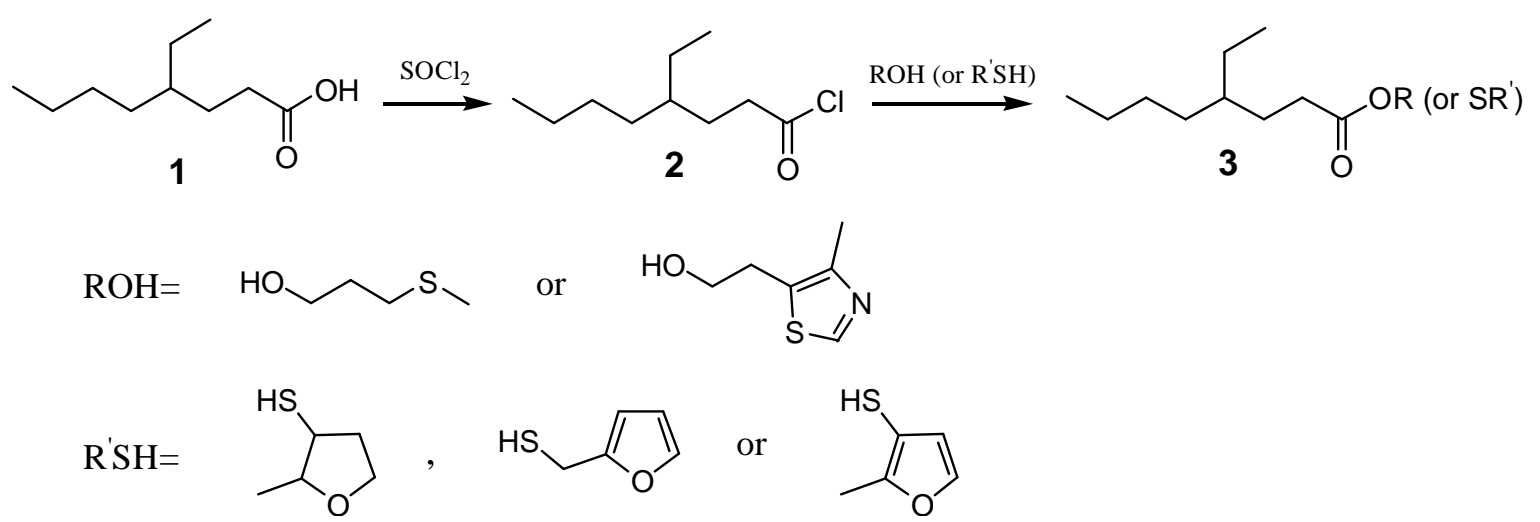
Figure 1. Structures of compounds 3a-e.<smiles>CCCCC(CC)CCC(=O)OCCCSC</smiles>

3a<smiles>CCCCC(CC)CCC(=O)OCCc1scnc1C</smiles>

3c<smiles>CCCCC(CC)CCC(=O)SC1CCOC1C</smiles>

$3 b$<smiles>CCCCC(CC)CCC(=O)SCc1ccco1</smiles>

$3 d$<smiles>CCCCC(CC)CCC(=O)Sc1ccoc1C</smiles>

The esters underwent odor evaluation, which demonstrated that these five synthetic sulfurcontaining flavor compounds all have meaty odor and might be used in foods if approved for this purpose in the future.

\section{Results and Discussion}

The effects of different mole ratios of materials on the yield were investigated using three different ratios under the same experimental conditions, and the results are shown in Table 1. Because the 4ethyloctanoic acid used was a racemic compound, the five synthesized flavor compounds are also racemic.

Table 1. Effect of different mole ratio of materials on the yield.

\begin{tabular}{|c|c|c|c|}
\hline \multirow{3}{*}{ Compound } & \multicolumn{3}{|c|}{ Yield (\%) } \\
\hline & \multicolumn{3}{|c|}{$n_{\text {(alcohol or mercaptan) }}: n_{\text {(4-ethyloctanoyl chloride) }}$} \\
\hline & 1.2:1 & 1.6:1 & 2.0: 1 \\
\hline 3a & $85 \%$ & $90 \%$ & $94 \%$ \\
\hline $\mathbf{3 b}$ & $67 \%$ & $78 \%$ & $94 \%$ \\
\hline 3c & $93 \%$ & $89 \%$ & $87 \%$ \\
\hline 3d & $93 \%$ & $94 \%$ & $95 \%$ \\
\hline $3 \mathbf{e}$ & $79 \%$ & $84 \%$ & $86 \%$ \\
\hline
\end{tabular}

The yields of $\mathbf{3 a}, \mathbf{3 b}, \mathbf{3 d}$ and $\mathbf{3 e}$ increased as the ratio of mercaptan (or alcohol) to 4-ethyloctanoyl chloride increased, while the yield of $\mathbf{3 c}$ decreased as the ratio of alcohol to 4-ethyloctanoyl chloride increased. This phenomenon was related to the characteristics of the starting materials involved in each reaction. In the reaction producing 3c, the 4-methyl-5-thiazoleethanol used as a starting material has multiple nucleophilic centers $(\mathrm{O}, \mathrm{S}$ and $\mathrm{N})$, which may react with 4-ethyloctanoic chloride to give the product or byproducts. Although the reaction temperature and steric-hindrance effect were not appropriate to form byproducts, the yield increased as the ratio of 4-methyl-5-thiazoleethanol to 4ethyloctanoyl chloride increased. This may account for the low yield of $\mathbf{3 c}$. 
The hydrogen chloride generated in the reactions to produce $\mathbf{3 d}$ and $\mathbf{3 e}$ induces the breakage of furan ring structure found in the starting material and the formation of resin-like byproducts. Pyridine was used in these reactions to trap the hydrogen chloride [23]. Pyridine can also react with 4-ethyloctanoyl chloride to give pyridine 4-ethyloctanoate, which readily forms the desired ester product with the mercaptan [24].

2-Methyl-3-furanthiol and 2-furanmethanethiol are isomers, where the latter one is more reactive than the former. The mercapto group of 2-methyl-3-furanthiol is adjacent to the conjugated system, which weakens its nucleophilicity. Consequently, the yield of $\mathbf{3 e}$ is lower than that of $\mathbf{3 d}$.

The odor evaluation results are shown in Table 2. The results indicate that the five synthetic sulfurcontaining flavor compounds all have meaty odor, especially $\mathbf{3 b}, \mathbf{3 d}$ and $\mathbf{3 e}$. Amongst those five compounds, the three derived from mercaptan and 4-ethyloctanyl chloride $(\mathbf{3 b}, \mathbf{3 d}$ and $\mathbf{3 e})$ have stronger odors than the two derived from a sulfur-containing alcohol and 4-ethyloctanyl chloride (3a and 3c). All five flavor compounds have relatively high molecular weights (> 260) and are therefore less volatile, which can prolong the flavoring lifetime to improve the flavoring quality.

Table 2. The results of odor evaluation.

\begin{tabular}{cc}
\hline Compound & Odor characteristics \\
\hline 3a & meaty, sauce, savory odor with a slight potato, radish and sulfury nuance \\
3b & meaty, onion, metallic, sulfury odor with a slight hot nuance \\
3c & a slight meaty, roasted and, burnt odor with sesame oil and fatty nuance \\
3d & meaty, roasted meat, onion, sulfury odor with a slight garlic nuance \\
3e & meaty, brothy, sulfury roasted odor with a slight sweet note \\
\hline
\end{tabular}

\section{Experimental}

\subsection{General}

The samples were analyzed by Varian CP3800 gas chromatography. Mass spectra were obtained using a Waters Micromass Q-TOF mass spectrometer. ${ }^{1} \mathrm{H}-\mathrm{NMR}$ and ${ }^{13} \mathrm{C}-\mathrm{NMR}$ spectra were obtained on a Bruker DRX-300 nuclear magnetic resonance spectrometer. IR spectra were acquired on a Nicolet Avater 370 Fourier transform infrared spectrometer. Odor evaluation was carried out by gas chromatography-olfactometry.

\subsection{Synthesis of 4-ethyloctanoyl chloride (2)}

To 4-ethyloctanoic acid $(0.2 \mathrm{~mol})$ was added thionyl chloride $(0.28 \mathrm{~mol})$ at $30{ }^{\circ} \mathrm{C}$. The resulting solution was refluxed for 6 hours at $80^{\circ} \mathrm{C}$, and the excess thionyl chloride was evaporated in vacuo to collect the distillate at $74{ }^{\circ} \mathrm{C} / 0.4 \mathrm{kPa}$ and give the 4-ethyloctanoyl chloride, yield $97 \%$. ${ }^{1} \mathrm{H}-\mathrm{NMR}$ $\left(\mathrm{CDCl}_{3}, \delta \mathrm{ppm}\right)$ 2.75-2.80 (t, 2H), 1.58-1.60 (m, 2H), 1.16-1.22 (m, 9H), 0.77-0.83 (m, 6H); ${ }^{13} \mathrm{C}-\mathrm{NMR}$ $\left(\mathrm{CDCl}_{3}, \delta \mathrm{ppm}\right) 174.10(\mathrm{C}=\mathrm{O}), 44.81\left(\mathrm{CH}_{2}\right), 37.89(\mathrm{CH}), 32.31\left(\mathrm{CH}_{2}\right), 28.67\left(\mathrm{CH}_{2}\right), 28.25\left(\mathrm{CH}_{2}\right)$, $25.41\left(\mathrm{CH}_{2}\right), 22.98\left(\mathrm{CH}_{2}\right), 14.06\left(\mathrm{CH}_{3}\right), 10.60\left(\mathrm{CH}_{3}\right)$; IR $\left(\mathrm{KBr}, \mathrm{cm}^{-1}\right) 2960,2929,2860,1801,1458$, 1404, 1380, 956, 709, 686, 596. 


\subsection{General Synthesis of Compounds 3a-c}

To alcohol (or mercaptan) $(0.1 \mathrm{~mol})$ was added 4-ethyloctanoyl chloride $(0.05 \mathrm{~mol})$ at $30{ }^{\circ} \mathrm{C}$, and the resulting solution was refluxed for 4 hours at $70^{\circ} \mathrm{C}$. After cooling, ethyl ether $(30 \mathrm{~mL})$ was added. The mixture was washed with $10 \% \mathrm{Na}_{2} \mathrm{CO}_{3}$ aqueous solution and saturated $\mathrm{NaCl}$ aqueous solution to pH 6-7, then the sample was dried with anhydrous $\mathrm{NaSO}_{4}$ and filtered. The ethyl ether was evaporated in vасио and the mixture was weighed. The composition of the product mixture was determined by gas-chromatography, and the yield was calculated. The product was further purified using distillation under the reduced pressure.

3-(Methylthio)propyl 4-ethyloctanoate (3a). Yield 94\%; b.p. $142{ }^{\circ} \mathrm{C} / 0.4 \mathrm{kPa}$; refractive index $\left(\mathrm{n}_{\mathrm{D}}{ }^{20}\right)$ 1.4654; MS (EI), m/z, $260.1812\left(\mathrm{M}^{+}\right)$, formula $\mathrm{C}_{14} \mathrm{H}_{28} \mathrm{O}_{2} \mathrm{~S}$, (calc. mass 260.1810). ${ }^{1} \mathrm{H}-\mathrm{NMR}\left(\mathrm{CDCl}_{3}, \delta\right.$ ppm) 4.14-4.18 (t, 2H), 2.53-2.58 (t, 2H), 2.25-2.30 (t, 2H), $2.10(\mathrm{~s}, 3 \mathrm{H}), 1.87-1.96(\mathrm{~m}, 2 \mathrm{H}), 1.55-1.60$ $(\mathrm{m}, 2 \mathrm{H}), 1.23-1.30(\mathrm{~m}, 9 \mathrm{H}), 0.84-0.90(\mathrm{~m}, 6 \mathrm{H}) ;{ }^{13} \mathrm{C}-\mathrm{NMR}\left(\mathrm{CDCl}_{3}, \delta \mathrm{ppm}\right) 173.82(\mathrm{C}=\mathrm{O}), 62.65$ $\left(\mathrm{OCH}_{2}\right), 38.25(\mathrm{CH}), 32.33\left(\mathrm{CH}_{2}\right), 31.60\left(\mathrm{CH}_{2}\right), 30.50\left(\mathrm{CH}_{2}\right), 28.66\left(\mathrm{CH}_{2}\right), 28.15\left(\mathrm{CH}_{2}\right), 28.12\left(\mathrm{CH}_{2}\right)$, $25.42\left(\mathrm{CH}_{2}\right), 22.91\left(\mathrm{CH}_{2}\right), 15.30\left(\mathrm{SCH}_{3}\right), 13.94\left(\mathrm{CH}_{3}\right), 10.57\left(\mathrm{CH}_{3}\right) ; \mathrm{IR}\left(\mathrm{KBr}, \mathrm{cm}^{-1}\right) 2958,2925,2864$, $1737,1460,1383,1349,1241,1168,1108,1024,960$.

2-Methyl-3-tetrahydrofuranthiol 4-ethyloctanoate (3b). Yield 94\%; b.p. $140^{\circ} \mathrm{C} / 0.2 \mathrm{kPa}$; refractive index $\left(\mathrm{n}_{\mathrm{D}}{ }^{20}\right)$ 1.4830; $\mathrm{MS}(\mathrm{EI}), \mathrm{m} / \mathrm{z},\left(\mathrm{M}^{+}\right)$272.1813, formula $\mathrm{C}_{15} \mathrm{H}_{28} \mathrm{O}_{2} \mathrm{~S}$, (calc. mass 272.1810). ${ }^{1} \mathrm{H}$ - NMR $\left(\mathrm{CDCl}_{3}, \delta \mathrm{ppm}\right)$ 4.09-4.13 (m, 0.5H), 3.95-4.03 (m, 0.5H), 3.89-3.93 (m, 1H), 3.70-3.82 (m, $1.5 \mathrm{H}), 3.48-3.53(\mathrm{~m}, 0.5 \mathrm{H}), 2.41-2.53(\mathrm{~m}, 3 \mathrm{H}), 1.82-1.86(\mathrm{~m}, 1 \mathrm{H}), 1.59-1.61(\mathrm{~m}, 2 \mathrm{H}), 1.16-1.26(\mathrm{~m}$, $12 \mathrm{H}), 0.80-0.88(\mathrm{~m}, 6 \mathrm{H}) ;{ }^{13} \mathrm{C}-\mathrm{NMR}\left(\mathrm{CDCl}_{3}, \delta \mathrm{ppm}\right) 199.48(\mathrm{C}=\mathrm{O}), 80.19(\mathrm{CH}-\mathrm{O}), 66.81\left(\mathrm{CH}_{2}-\mathrm{O}\right)$, $46.47(\mathrm{CH}-\mathrm{S}), 41.68\left(\mathrm{CH}_{2}\right), 38.33(\mathrm{CH}), 33.39\left(\mathrm{CH}_{2}\right), 32.51\left(\mathrm{CH}_{2}\right), 29.05\left(\mathrm{CH}_{2}\right), 28.83\left(\mathrm{CH}_{2}\right), 25.60$ $\left(\mathrm{CH}_{2}\right), 23.11\left(\mathrm{CH}_{2}\right), 17.00\left(\mathrm{CH}_{3}\right), 14.19\left(\mathrm{CH}_{3}\right), 10.77\left(\mathrm{CH}_{3}\right) ; \mathrm{IR}\left(\mathrm{KBr}, \mathrm{cm}^{-1}\right) 2959,2928,2872,1692$, 1456, 1380, 1352, 1315, 1188, 1111, 1063, 1022, 990, 858.

4-Methyl-5-thiazoleethanol 4-ethyloctanoate (3c). Yield 93\%; b.p. $175{ }^{\circ} \mathrm{C} / 0.4 \mathrm{kPa}$; refractive index $\left(\mathrm{n}_{\mathrm{D}}{ }^{20}\right)$ 1.4920; MS (EI), m/z, $297.1766\left(\mathrm{M}^{+}\right)$, formula $\mathrm{C}_{16} \mathrm{H}_{27} \mathrm{O}_{2} \mathrm{SN}$, (calc. mass 297.1763); ${ }^{1} \mathrm{H}-\mathrm{NMR}$ $\left(\mathrm{CDCl}_{3}, \delta \mathrm{ppm}\right) 8.55(\mathrm{~s}, 1 \mathrm{H}), 4.17-4.21(\mathrm{t}, 2 \mathrm{H}), 3.03-3.08(\mathrm{t}, 2 \mathrm{H}), 2.38(\mathrm{~s}, 3 \mathrm{H}), 2.22-2.27(\mathrm{~m}, 2 \mathrm{H})$, 1.53-1.55 (m, 2H), 1.19-1.24 (m, 9H), 0.78-0.87 (m, 6H); ${ }^{13} \mathrm{C}-\mathrm{NMR}\left(\mathrm{CDCl}_{3}, \delta \mathrm{ppm}\right) 173.90(\mathrm{C}=\mathrm{O})$, $149.86(\mathrm{~S}-\mathrm{CH}=\mathrm{N}), 149.77(\mathrm{~N}-\mathrm{C}), 126.75(\mathrm{~S}-\mathrm{C}), 63.81\left(\mathrm{O}-\mathrm{CH}_{2}\right), 38.28(\mathrm{CH}), 32.36\left(\mathrm{CH}_{2}\right), 31.65\left(\mathrm{CH}_{2}\right)$, $28.72\left(\mathrm{CH}_{2}\right), 28.07\left(\mathrm{CH}_{2}\right), 25.77\left(\mathrm{CH}_{2}\right), 25.45\left(\mathrm{CH}_{2}\right), 23.03\left(\mathrm{CH}_{2}\right), 14.90\left(\mathrm{CH}_{3}\right), 14.10\left(\mathrm{CH}_{3}\right), 10.68$ $\left(\mathrm{CH}_{3}\right)$; IR $\left(\mathrm{KBr}, \mathrm{cm}^{-1}\right) 2958,2926,2860,1738,1543,1458,1416,1378,1238,1167,1106,1035,915$, $847,786$.

\subsection{General Synthesis of Compound 3d-e}

A mixture of 2-furanmethanethiol(or 2-methyl-3-furanthiol) $(0.1 \mathrm{~mol})$, pyridine $(0.1 \mathrm{~mol})$ and dichloromethane $(40 \mathrm{~mL})$ was prepared and to this was added 4-ethyloctanoyl chloride $(0.05 \mathrm{~mol})$ at $30{ }^{\circ} \mathrm{C}$. The resulting solution was refluxed for 6 hours at $45^{\circ} \mathrm{C}$. At the end of this period, the mixture was filtered to remove solids, and the filtrate was washed with saturated $\mathrm{NaCl}$ aqueous solution. The organic phase was dried with anhydrous $\mathrm{NaSO}_{4}$ and filtered. Dichloromethane and pyridine were 
evaporated in vacuo and the mixture weighed. The composition of the product was determined by gaschromatography and the yield calculated. The product was further purified via distillation under reduced pressure.

2-Furanmethanethiol 4-ethyloctanoate (3d). Yield 95\%; b.p. $142{ }^{\circ} \mathrm{C} / 0.3 \mathrm{kPa}$; refractive index $\left(\mathrm{n}_{\mathrm{D}}{ }^{20}\right)$ 1.5005; MS (EI), m/z, $268.1500\left(\mathrm{M}^{+}\right)$, formula $\mathrm{C}_{15} \mathrm{H}_{24} \mathrm{O}_{2} \mathrm{~S}$, (calc. mass 268.1497); ${ }^{1} \mathrm{H}-\mathrm{NMR}\left(\mathrm{CDCl}_{3}, \delta\right.$ ppm) $7.31(\mathrm{~m}, 1 \mathrm{H}), 6.27(\mathrm{~m}, 1 \mathrm{H}), 6.19-6.20(\mathrm{~m}, 1 \mathrm{H}), 3.03-3.08(\mathrm{t}, 2 \mathrm{H}), 4.13(\mathrm{~s}, 2 \mathrm{H}), 2.51-2.56(\mathrm{~m}$, $2 \mathrm{H}), 1.63(\mathrm{~m}, 2 \mathrm{H}), 1.23-1.28(\mathrm{~m}, 9 \mathrm{H}), 0.81-0.90(\mathrm{~m}, 6 \mathrm{H}) ;{ }^{13} \mathrm{C}-\mathrm{NMR}\left(\mathrm{CDCl}_{3}, \delta \mathrm{ppm}\right) 198.54(\mathrm{C}=\mathrm{O})$, 150.61 (=C-O), 142.13 (=CH-O), $110.53(\mathrm{CH}=), 107.82(\mathrm{CH}=), 41.41\left(\mathrm{CH}_{2}\right), 38.24(\mathrm{CH}), 32.42$ $\left(\mathrm{CH}_{2}\right), 28.73\left(\mathrm{CH}_{2}\right), 25.63\left(\mathrm{CH}_{2}\right), 25.55\left(\mathrm{CH}_{2}\right), 25.51\left(\mathrm{CH}_{2}\right), 23.03\left(\mathrm{CH}_{2}\right), 14.10\left(\mathrm{CH}_{3}\right), 10.68\left(\mathrm{CH}_{3}\right)$; IR $\left(\mathrm{KBr}, \mathrm{cm}^{-1}\right) 2958,2927,2859,1694,1596,1502,1460,1380,1246,1151,1071,1010,935,885$, $807,735,597$.

2-Methyl-3-furanthiol 4-ethyloctanoate (3e). Yield 86\%; b.p. $134{ }^{\circ} \mathrm{C} / 0.2 \mathrm{kPa}$; Refractive index $\left(\mathrm{n}_{\mathrm{D}}{ }^{20}\right.$ ) 1.4960; MS (EI), m/z, $268.1499\left(\mathrm{M}^{+}\right)$, formula $\mathrm{C}_{15} \mathrm{H}_{24} \mathrm{O}_{2} \mathrm{~S}$, (calc. mass 268.1497); ${ }^{1} \mathrm{H}-\mathrm{NMR}\left(\mathrm{CDCl}_{3}, \delta\right.$ ppm) 7.35-7.36 (d, 1H), 6.31-6.32 (d, 1H), 2.59-2.62 (t, 2H), $2.26(\mathrm{~s}, 3 \mathrm{H}), 1.63-1.70(\mathrm{~m}, 2 \mathrm{H}), 1.26-1.32$ $(\mathrm{m}, 9 \mathrm{H}), 0.84-0.92(\mathrm{~m}, 6 \mathrm{H}) ;{ }^{13} \mathrm{C}-\mathrm{NMR}\left(\mathrm{CDCl}_{3}, \delta \mathrm{ppm}\right) 197.49(\mathrm{C}=\mathrm{O}), 155.92$ (=C-O), 140.88 (=CH-O), $114.78(\mathrm{CH}=), 104.30(\mathrm{~S}-\mathrm{C}), 40.70\left(\mathrm{CH}_{2}\right), 38.25(\mathrm{CH}), 32.41\left(\mathrm{CH}_{2}\right), 28.71\left(\mathrm{CH}_{2}\right), 28.68$ $\left(\mathrm{CH}_{2}\right), 25.50\left(\mathrm{CH}_{2}\right), 22.95\left(\mathrm{CH}_{2}\right), 13.99\left(\mathrm{CH}_{3}\right), 11.78\left(\mathrm{CH}_{3}\right), 10.62\left(\mathrm{CH}_{3}\right)$; IR $\left(\mathrm{KBr}, \mathrm{cm}^{-1}\right) 2959,2926$, 2859, 1715, 1588, 1514, 1387, 1228, 1129, 1090, 1020, 940, 889, 728, 648, 603, 525.

\subsection{Odor evaluation}

These compounds were purified by column chromatography. Odor assessments were carried out by using a Agilent 6890 GC coupled with a Sniffer 9000 system. Separations were achieved with a HP-5 capillary column, $30 \mathrm{~m} \times 0.250 \mathrm{~mm}$; with a programmed temperature ramp, $\left(200{ }^{\circ} \mathrm{C}\right.$, holding for $2 \mathrm{~min}$, then programmed to $300{ }^{\circ} \mathrm{C}$ at $10^{\circ} \mathrm{C} / \mathrm{min}$ and held at $300{ }^{\circ} \mathrm{C}$ for $2 \mathrm{~min}$; injection temperature, $280{ }^{\circ} \mathrm{C}$ ) detector (FID) temperature at $300^{\circ} \mathrm{C}$. By one ' $\mathrm{Y}$ ' shape glass splitter, the column effluent was divided (1:1) between the flame ionization detector (FID) and the olfactometer (Sniffer 9000). The effluent to the odor port was enclosed with a stream of humidified air of $6 \mathrm{~mL} / \mathrm{min}$ and transferred to the glass detection cone by one long capillary at the temperature of $280{ }^{\circ} \mathrm{C}$. Five trained assessors were selected for smelling and recording the odor characteristics [25,26].

\section{Conclusions}

We report the synthesis and odor evaluation of sulfur-containing esters derived from 4-ethyloctanoic acid. The structures of five new flavor compounds were characterized by $\mathrm{MS},{ }^{1} \mathrm{H}-\mathrm{NMR},{ }^{13} \mathrm{C}$ NMR and IR, and odor evaluation indicated they all have meaty odors. This research will be helpful to develop new flavor compounds based on organic acid and sulfur-containing alcohols (or mercaptans).

\section{Acknowledgements}

The project was supported by Beijing Municipal Party Committee Organization Department (No: 20081D0500300127) 


\section{References and Notes}

1. Habib, F.; Nasser, I.; Mohammad, A. Pronounced catalytic effect of a micellar solution of sodium dodecyl sulfate (SDS) on the efficient C-S bond formation via an odorless thia-Michael addition reaction through the in situ generation of S-alkylisothiouronium salts. Adv. Synth. Catal. 2009, 351, 755-766.

2. Habib, F.; Nasser, I.; Mohammad, A. A facile generation of C-S bonds via one-pot, odourless and efficient thia-Michael addition reactions using alkyl, aryl or allyl halides, thiourea and electrondeficient alkenes in wet polyethylene glycol (PEG 200) under mild reaction conditions. Tetrahedron 2009, 65, 5293-5301.

3. Beletskaya, I.P.; Tarasenko, E.A.; Khokhlov, A.R. Poly(N-vinylimidazole) as efficient and recyclable catalyst for the addition of thiols to Michael acceptors in aqueous medium. Russ. J. Org. Chem. 2007, 43, 1733-1736.

4. Tachibana, S.; Kasemura, K.; Ohtani, T. Synthesis and physiological activity of S-furfuryl thiocarboxylates. Nippon Nogei Kagaku Kaishi 2002, 76, 962-969.

5. Shimizu, H.; Sagara, R.; Aizawa, S. Preparation of amino group-containing esters by using solid superstrong acid catalysts. JP 06321878, 22 November 1994.

6. Boustany, K.S. Addition of methanethiol to some $\alpha, \beta$-unsaturated aldehydes and study of the reduction and acetalization of the addition products. J. Chem. U.A.R. 1966, 9, 317-322.

7. Liu,Y.P.; Sun, B.G.; Zheng, F.P. Synthesis of 3-(methylthio)propyl acetate. Shipin gongye keji 2005, 26, 159-160.

8. Tadashi, S. Comparison of the activity of different aneurine esters of organic acids. Bull. Chem. Soc. Jpn. 1944, 19, 185-205.

9. Ayers, J.A.; Anderson, S.R. A preparative scale reduction of alkyl disulfides with tributyl phophine and water. Synth. Commun. 1999, 29, 351-358.

10. Winter, M.; Gautschi, F.; Flament, I. Flavoring agent. US Pat. 3,931,245, 6 January 1976.

11. Evers, W. J.; Heinsohn, H.H.; Mayers, B.J. Novel flavoring compositions and products comprising 2,5-dimethyl-3-thioisovaleryl furan. US Pat. 3,958,029, 18 May 1976.

12. Evers, W.J.; Heinsohn, H.H.; Mayers, B.J. Novel flavoring compositions and products containing 2-methyl-3-thio-(2-methylbutyryl)-furan. US Pat. 3,961,093, 1 June 1976.

13. Evers, W.J.; Heinsohn, H.H.; Mayers, B.J. 3-Furyl thioesters to impart meaty aroma and taste. US 3,917,869, 4 November 1975.

14. Evers, W.J.; Mayers, B.J.; Heinson, H.H. Acylthiofuran derivatives and their use as flavors. DE 2437890, 20 February 1975.

15. Huang, X.J.; Liu, C.C. Synthesis of perfume furfuryl thiopropionate. Riyong huaxue gongye 2007, 37, 417-418.

16. Ouweland,V.D.; Maria G.A.; Peer, H.G. Compounds for giving aroma to foods. AT 340748, 27 December 1977.

17. Boelens, H.; Haring, H. G.; Rijke, D.D. Threshold values of and human preferences for 4-ethyl octanoic and 3-methyl butanoic acid. Perfum. Flavor. 1983, 8, 71-73.

18. Mosciano, G. Organoleptic characteristics of flavor materials. Perfum. Flavor. 2007, 32, 16-18.

19. Mosciano, G. Organoleptic characteristics of flavor materials. Perfum. Flavor. 2006, 31, 48-51. 
20. Mosciano, G.; Fasano, M.; Cassidy, J. Organoleptic characteristics of flavor materials. Perfum. Flavor. 1993, 18, 51-53.

21. Sun, B.G. Sulfur-Containing Flavour Chemistry(in Chinese); Science Press: Beijing, China, 2007; pp.41-70.

22. Mosciano, G. Organoleptic characteristics of flavor materials. Perfum. Flavor. 2001, 26, 68-72.

23. Wang, G.Y.; Liu, X.J.; Li; L.B. Synthesis of perfume furfuryl butyrate and its characterization. Jingxi Huagong 2004, 21, 589-590.

24. Zheng, F.P.; Sun, B.G.; He, J. Syntheses of ethylthiol furoate and furfurylthiol furoate. Jingxi Huagong 1997, 14, 17-19.

25. Wu, R.K. Aromatics-Method for Evaluation of Odor; GB/T 14454.2-1993. Standards press of China: Beijing, China, 1993.

26. Xie, J.C.; Sun, B. G; Wang, S.B. Aromatic constituents from Chinese traditional smoke-cured bacon of Mini-pig. Food Sci. Tech. Int. 2008, 14, 329-340.

Sample Availability: Samples of the compounds $\mathbf{3 a - 3 e}$ are available from the authors.

(C) 2010 by the authors; licensee MDPI, Basel, Switzerland. This article is an Open Access article distributed under the terms and conditions of the Creative Commons Attribution license (http://creativecommons.org/licenses/by/3.0/). 